\title{
PEMBERDAYAAN REMAJA USIA SEKOLAH DALAM PELATIHAN PEMBUATAN ANEKA ASINAN BUAH PASAR DI KELURAHAN DANGERAKKO KOTA PALOPO
}

\author{
Rosmalah Yanti ${ }^{*}$ \\ Ulfah Zakiyah²
}

1Pendidikan Guru Sekolah Dasar Universitas Cokroaminoto Palopo, Palopo, Indonesia

${ }^{2}$ Agroteknologi Universitas Cokroaminoto Palopo, Indonesia

rosmalah@uncp.ac.id ${ }^{\left.1^{*}\right)}$

ulfahzakiyah@uncp.ac.id 2)

Kata Kunci: [Asinan, Aneka Buah, Pelatihan Remaja]

\begin{abstract}
Abstrak: Kegiatan ini didasari oleh fakta bahwa waktu luang para remaja yang bersekolah secara daring di Kelurahan Dangerakko Kota Palopo yang cukup banyak. Berdasarkan observasi lapangan, selain mengikuti sekolah secara daring, para remaja menghabiskan waktunya dengan berjualan online, menyelesaikan pekerjaan rumah dan update status. Kegiatan ini diselenggarakan dengan tujuan memberi pengetahuan baru bagi para remaja dan mendorongnya untuk berwirausaha dengan produk yang dihasilkan. Kegiatan dilakukan secara bertahap di beberapa RT/RW di kelurahan Dangerakko dengan peserta yaitu remaja usia sekolah (13-19 tahun) yang bersekolah secara daring bertempat tinggal di Kelurahan Dangerakko Kota Palopo. Pelatihan yang diberikan antara lain membuat saus spesial untuk asinan, memilih aneka buah yang cocok dijadikan asinan serta menatanya menjadi asinan buah dengan berbagai tekstur yang menarik. Buah pasar yang diolah menjadi asinan antara lain salak, kedondong, timun, dan mangga. Pelatihan di setiap RT/RW di kelurahan Dangerakko memakan waktu 3 hari dan pelaksanaan kegiatan secara keseluruhan sekitar 4 pekan. Jumlah peserta kegiatan di setiap RT/RW dibatasi maksimal 4 orang per kegiatan. Dari 7 kelompok peserta, sebanyak 4 orang diantaranya memasarkan produk asinan buah secara daring. Pelaksanaan kegiatan pelatihan pembuatan asinan buah menarik animo peserta kegiatan untuk berlatih dan mengembangkan ide baru untuk berwirausaha.
\end{abstract}

\section{Pendahuluan}

Meningkatnya kasus Covid-19 di Kota Palopo membuat Pemerintah Kota menyetujui anjuran Pemerintah Pusat untuk melakukan aktivitas secara daring dari rumah. Hal ini berdampak pada kegiatan para remaja usia sekolah. 90\% Responden remaja yang mengisi angket daring pada observasi awal pelaksana kegiatan menyatakan bahwa waktu luang sepanjang pelaksanaan sekolah daring dihabiskan dengan update 
status, berjualan secara daring dan membantu orang tua di rumah. Selama pandemi Covid-19, sangat dianjurkan untuk menerapkan pola hidup bersih dan sehat yang salah satunya adalah makan buah. Diketahui bahwa permintaan buah meningkat selama pandemi Covid-19 (Gatra, Agustus 2020). Namun, buah-buahan yang dilepas ke pasaran musiman, cepat rusak dan dengan ukuran yang beragam. Diperlukan usaha untuk menanggulangi sifat buah-buahan ini. Olahan buah tanpa mengubah vitamin, memberi warna mencolok dan meningkatkan rasa buah perlu dilakukan agar meningkatkan selera makan buah.

Asinan buah dipilih menjadi salah satu variasi olahan buah untuk meningkatkan selera makan buah bagi masyarakat. Asinan buah dapat meningkatkan pencernaan dan memberikan pengalaman aneka tekstur bagi yang memakannya (FAO/WHO, 2009). Sumiati, et. al. (2015) menyatakan bahwa asinan buah merupakan kuliner berupa acar buah. Asinan buah dapat diproses melalui 2 (dua) cara. Cara pertama dengan menggunakan larutan garam 16\% tanpa melibatkan fermentasi. Cara lainnya dengan merendam buah potong dalam cuka, garam dan sedikit gula untuk memperkaya rasa dan tekstur (Behera, et. al. 2020). Fermentasi yang terjadi dalam pengolahan asinan buah dapat menghambat kinerja bakteri yang secara langsung mengawetkan buah potong tersebut.

Aneka buah pasar yang bertekstur keras dapat diolah menjadi asinan buah. Mangga dapat dibuat menjadi asinan kering, asinan berminyak, asinan berasa asam manis (Saroj, 2018). Timun yang mengandung 90\% air juga dapat diolah menjadi asinan buah (Uthpala et. al, 2019). Penambahan garam dalam olahan asinan salak dapat memperpanjang umur simpan salak (Setiawan \& Dewi, 2016).

Berdasarkan fakta yang telah dijabarkan, asinan buah berbahan dasar buah lokal yang beredar di pasaran dapat dilakukan. Pelaksana kegiatan berinisiatif mengisi waktu luang para remaja ini dengan memberdayakannya dalam kegiatan pelatihan pembuatan asinan buah. Kegiatan ini diharapkan dapat memperluas pengetahuan yang dimiliki para remaja usia sekolah dan memperkaya ide berwirausahanya masing-masing.

\section{Metode Pelaksanaan}

Kegiatan ini memuat sosialisasi dan pelaksanaan pelatihan asinan buah dari aneka buah pasar. Pelaksanaan kegiatan bertempat di Kelurahan Dangerakko Kecamatan Wara Kota Palopo (Gambar 1). Sasaran pelaksanaan kegiatan yaitu remaja usia sekolah yang mengikuti kegiatan sekolah secara daring dari rumah. Peserta dipilih secara acak dan insidentil dan dibatasi maksimal 4 orang per kelompok per RT/RW. Pelatihan terdiri atas pembuatan saus spesial untuk asinan, preparasi buah pasar siap olah dan pelatihan kombinasi tekstur buah yang cocok untuk asinan buah. Pelatihan dilakukan dengan metode eksperimen (peserta kegiatan langsung mempraktikkan pembuatan asinan buah bersama pelaksana kegiatan). Keberhasilan peserta dalam pelatihan diukur dari kemampuan peserta dalam membuat ulang asinan buah. Sebagai bahan evaluasi, di akhir pelaksanaan kegiatan, setiap kelompok peserta kegiatan akan diminta untuk mengirimkan sampel asinan buah yang diolah sendiri dan dinilai oleh masyarakat sekitar dan pelaksana kegiatan untuk rasa yang disukai. 


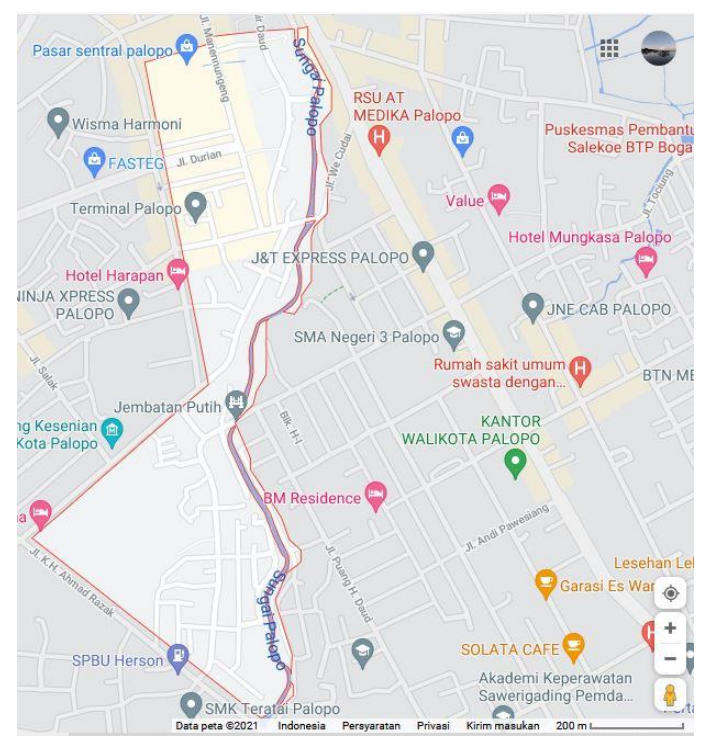

Gambar 1. Peta lokasi pelaksanaan kegiatan

\section{Hasil dan Pembahasan}

Kegiatan pelatihan diikuti dengan antusias oleh peserta kegiatan. Pada saat pelaksanaan, buah yang dikumpulkan oleh peserta kegiatan adalah kedondong, salak, timun, dan mangga. Waktu pelaksanaan kegiatan untuk setiap kelompok peserta berbeda dan menyesuaikan waktu luang para peserta. Gambar 2 menyajikan Sebagian peralatan dan bahan yang dipakai pada pelaksanaan kegiatan.

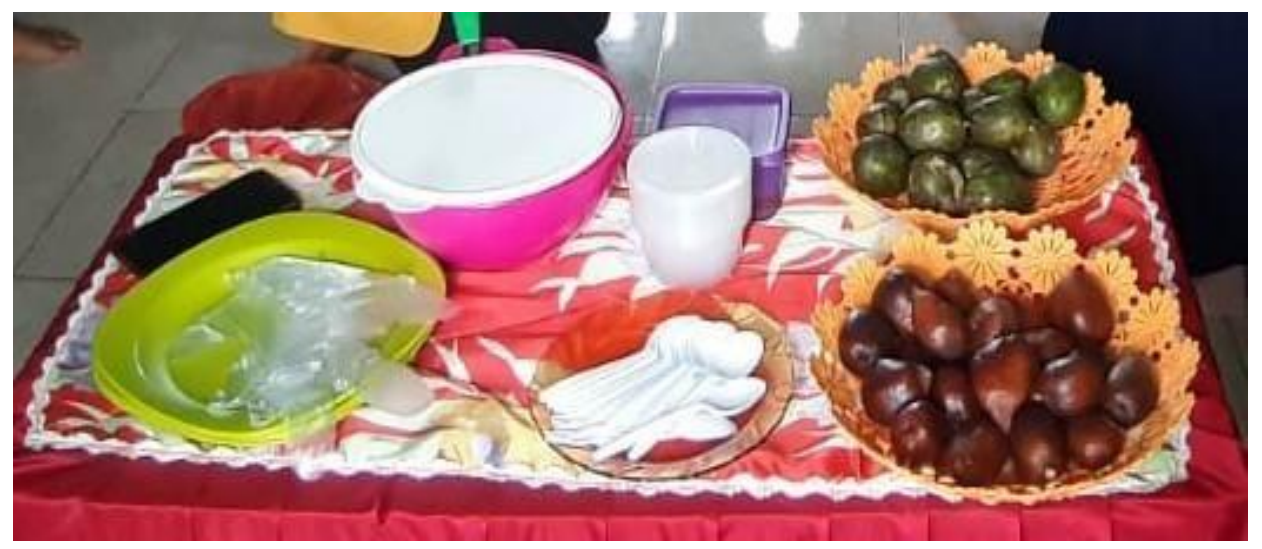

Gambar 2. Alat dan bahan pada pelaksanaan kegiatan

Pelaksanaan kegiatan terdiri atas pembuatan saus spesial (Gambar 3). Saus spesial terdiri atas campuran halus bawang putih, bawang merah, gula, cuka, cabai dan garam. Sebelum digunakan, saus terlebih dahulu dididihkan dan didinginkan. Hasil akhir saus berwarna jingga kemerahan. 


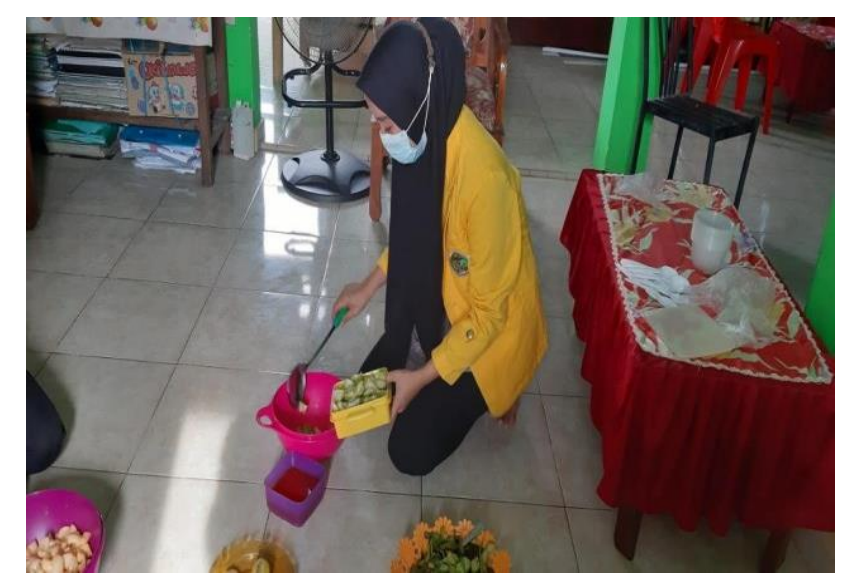

Gambar 3. Proses pembuatan saus spesial

Pemilihan buah dan pemotongan buah untuk memperoleh tekstur (setelah fermentasi) yang baik (Gambar 4) dimulai dengan mengumpulkan buah kemudian dipotong kecil berukuran ruas jari.

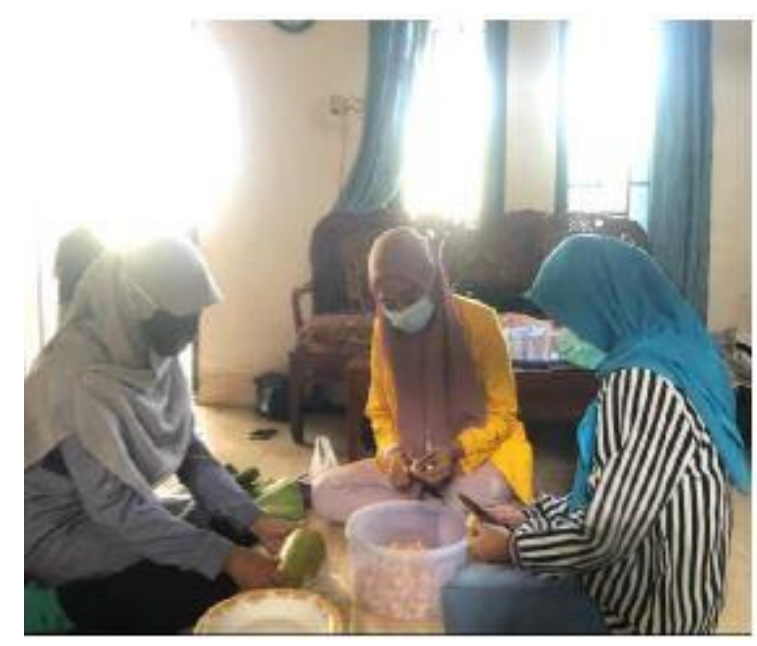

Gambar 4. Pemotongan buah pilihan bersama peserta kegiatan

Buah yang telah dipotong selanjutnya dicampurkan dengan saus spesial dan dibiarkan semalaman dalam keadaan tertutup pada suhu rendah. Contoh produk asinan buah yang dibuat pada kegiatan pelatihan ini disajikan pada Gambar 5.

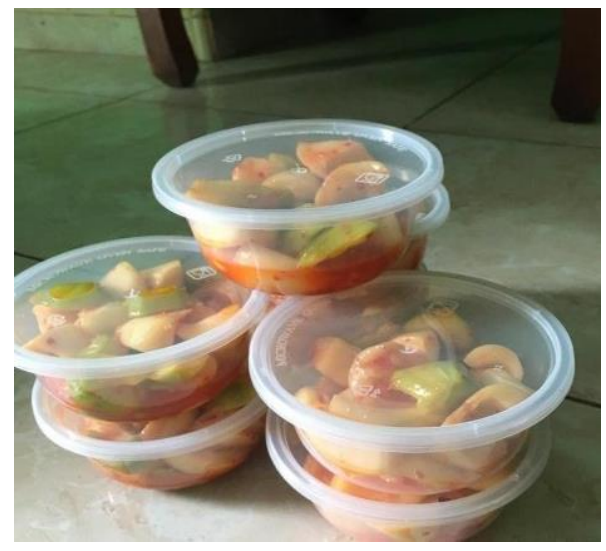

Gambar 5. Produk asinan buah yang dibuat bersama peserta kegiatan

Asinan buah yang dibiarkan semalam mulai mengeluarkan cairan kental dengan rasa sesuai saus. Tekstur buah menjadi lebih lembut namun dapat bertahan selama 5 hari pada 
suhu rendah. Asinan makanan yang diproses secara tradisional menawarkan warna, rasa dan tekstur yang kaya (Gadeckar et. al, 2010).

Evaluasi asinan buah yang dibuat oleh peserta kegiatan (Gambar 6) dinilai langsung oleh masyarakat. Setiap kelompok peserta menyediakan sampel asinan buah untuk dicoba setiap masyarakat penilai. Semakin banyak produk asinan buah yang diambil, semakin baik rasa asinan buah tersebut.

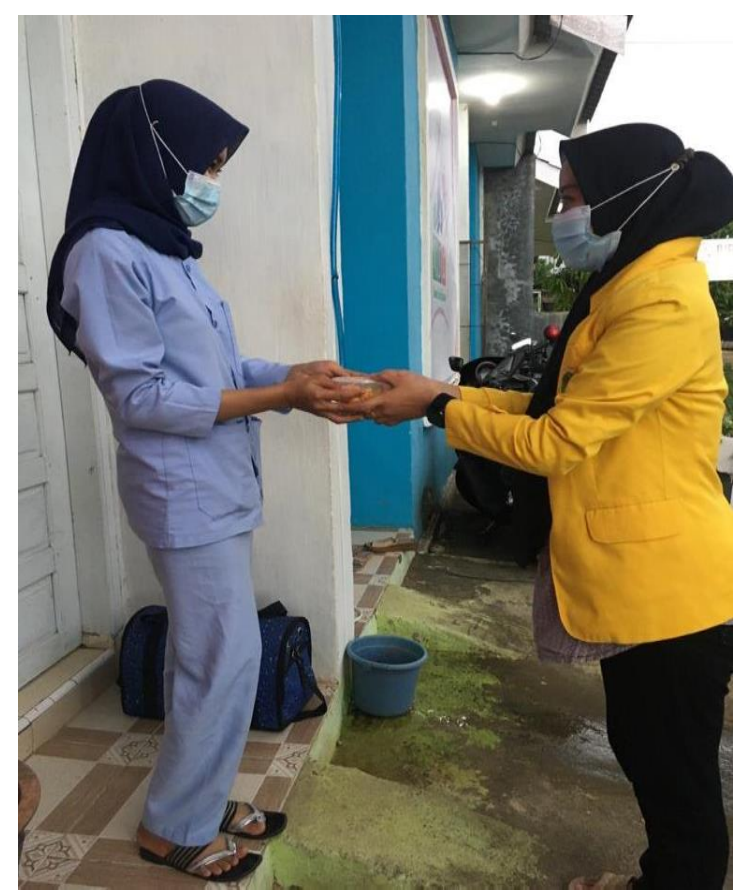

Gambar 6. Penyerahan produk asinan buah yang dibuat peserta kegiatan

\section{Kesimpulan}

Berdasarkan pelaksanaan kegiatan yang telah dilakukan, beberapa hal yang dapat disimpulkan antara lain:

1. Asinan buah dapat menjadi alternatif olahan buah untuk mempertahankan umur simpan dan meningkatkan rasa

2. Asinan buah dapat menjadi salah satu ide berwirausaha bagi remaja usia sekolah

Pengembangan untuk kegiatan selanjutnya adalah pelatihan asinan buah untuk ibu rumah tangga dan uji organoleptik untuk produk asinan buah yang dihasilkan.

\section{Ucapan Terimakasih}

Ucapan terima kasih sebesar-besarnya dihaturkan kepada Universitas Cokroaminoto Palopo, aparat pemerintah setempat serta peserta kegiatan atas kerjasama dan keikutsertaan dalam kegiatan.

\section{Referensi}

Anonim, (2020, 10 Agustus). Selama Pandemi, Permintaan Buah Lokal Meningkat Tajam. Gatra. Diakses dari https://www.gatra.com/detail/news/487043/ekonomi/selama-pandemi permintaan-buah-lokal-melonjak-tajam. 
Behera, Sudhanshu S., Aly Farag El Sheikha, Riadh Hammammi, Awanish Kumar. (2020). Traditionally Fermented Pickles: How the Microbial Diversity Associated with Their Nutritional and Health Benefits? Journal of Functional Foods, 70. https://doi.org/10.1016/i.jff.2020.103971

Food and Agriculture Organization of the United Nations/World Health Organization (FAO/WHO), (2002). Guidelines for the evaluation of probiotics in food. Report of a joint FAO/WHO working group on drafting guidelines for the evaluation of probiotics in food. London, Ontario, Canada.

Gadekar, Y. P., Kokane, R. D., Suradkar, U. S., Thomas, R., Das, A. K., \& Anjaneyulu, A. S. R. (2010). Shelf stable meat pickles - A review. International Food Research Journal, 17, 221-227. Retrieved from http://www.ifrj.upm.edu.my/17\%20(02)\%202010/IFRJ-2010-221227_Gadekar_India[1].pdf

Saroj, \& Singh, K. K. (2018). Standardization of recipe and method for mango pickle. International Journal of Chemical Studies, 6, 2033-2037. Retrieved from https://www.semanticscholar.org/paper/Standardization-of-recipe-and-methodfor-mango-Saroj-Singh/37f4c7f1385160ea77df38c4e8c9d2e97470d17e\#citingpapers

Sumiati, -, Suroso, A., Wirman, S. P., \& Retnawaty, S. F. (2015). Uji pH dan Karakter Fisis pada Akhir Manisan Buah Salak Sidempuan (Salacca sumatrana). Photon: Jurnal Sain Dan Kesehatan, 5(2), 43-52. https://doi.org/10.37859/jp.v5i2.585

Setiawan, Nugroho A., \& Susilo Dewi, S. (2016). Pemberdayaan Kelompok Aisyiyah dalam Pengelolaan Salak Pondoh di Kecamatan Turi, Sleman. BERDIKARI : Jurnal Inovasi Dan Penerapan Ipteks, 4(2), 63-72. https://doi.org/10.18196/bdr.427

Uthpala, T. G. G., Marapana, R. A. U. J., Rathnayake A. R. M. H. A., Maduwanthi, S. D. T. 2019. Cucumber Vegetable as A Brine Fermented Pickle. Trends \& Prospects in Processing of Horticultural Crops, 447-462. Retrieved from https://www.researchgate.net/profile/T-G-G-Uthpala-

2/publication/331533088_CUCUMBER_VEGETABLE_AS_A_BRINE_FERMENTED_P ICKLE/links/5c7eb7e392851c695058a930/CUCUMBER-VEGETABLE-AS-ABRINE-FERMENTED-PICKLE.pdf 